\title{
Students' Digital Ethics Profile in the Era of Disruption: An Overview from the Internet Use at Risk in Surakarta City, Indonesia
}

\author{
https://doi.org/10.3991/ijim.v14i03.12207 \\ Dewi Ika Sari ( $\left.{ }^{\bowtie}\right)$, Triana Rejekiningsih, Moh. Muchtarom \\ Sebelas Maret University, Kota Surakarta, Indonesia \\ dewiika@student.uns.ac.id
}

\begin{abstract}
This study aims to reveal students' profile of digital ethics in Surakarta City, Indonesia. Current technological trends generate significant implications for the technological digitalizations to all parts of human lives. Information and Communication Technology (ICT) is increasingly integrated in society. This condition at least triggers the emergence of an era of disruption due to changes in the order and lifestyle of the younger generation who prefer the use of various digital technologies in their daily life activities. In recent years, a lot of discussion about the risks and opportunities of digital technology on teenagers have been many found. From several studies conclude that the highest students' communication activities have been majorly done through online. Internet at risk use engages students' live activities, among others, expressing personal data, bullying, hoaxes, and hate speech to accessing the pornographic contents. Digital ethics is one of the components in digital citizenship from which the users must adhere to. Netiquette, a hybrid word combining "network" and "etiquette," essentially referring to the social code of the Internet. As netiquette includes how we communicate, treat others, describe and protect ourselves online related to ethical issues. This study was designed with a quantitativedescriptive research model that applies the survey method. The survey was conducted in three schools, each of which was the high school, the state vocational school and private vocational high school in the Surakarta residency area. The study subjects involved as many as 210 students, from ages 15 to 17 years participating in the survey. The questionnaire consisted of 16 statements applying Likert's point of scale one to five. The results showed that students' digital ethics with having fewer categories had the highest percentage of $35.23 \%$. While those with enough category reached $32.85 \%$ and those with good category was $31.90 \%$. One of the effective ways to strengthening students' digital ethics can be realized through humanistic literacy, which is integrated into Civics Education subject at schools.
\end{abstract}

Keywords-Digital ethics, era of disruption, internet use. 


\section{Introduction}

Current technological trend introduced to society has led the presence of digitalization in all sectors of modern human life society. Information and Communication Technology (ICT) is increasingly integrated at the heart of society. The rapid development of mobile technology and communication computing in the past few years has provided opportunities for social communication to penetrate geographical boundaries [28]. The Ministry of Information and Communication revealed that the survey results from eMarketer.com showed that the number of internet users around the world would reach 3 billion in 2015. Moreover, in 2018, as many as 3.6 billion people on earth have been predicted to access the internet at least once every month. Affordable mobile phones and mobile broadband connections are driving growth in internet access in countries that cannot rely on the fixed line, either because of infrastructure problems or costs, according to senior eMarketer analyst Monica Peart. Almost every resident of the regions in the archipelago is connected via the internet. Indonesia is ranked sixth most internet users in the world. This expanding connectivity is associated with what many consider to be the peak of cellular communication technology. Sophisticated Smartphone that integrates various functions in one hand [8].

A number of communication tools such as computers, notebooks, smartphones and access to the internet are mostly received directly by young citizens in many countries [26]. It is unsurprisingly to say that this condition changes the lifestyle of citizens who are easily adapted to technology in addition to being a major challenge especially for students of modern times [7].Among the reasons for students use of internet have been means of communication, surfing media to find sources of learning, entertainment and self-expression. Including those that significantly affect these activities where the digital environment has been adapted and transformed into applied media in a variety of basic activities in schools such as reading, writing and interpersonal communication skills of students [20]. This condition has at least succeeded in triggering an era of disruption due to changes in the order and lifestyle of the younger generation who prefer to use various digital technologies in their life activities. The ease of accessing information, changes in communication patterns, and how to obtain knowledge through digital media is a feature of the era of disruption [17].

In recent years, there has been much discussion about the risks and opportunities for digital technology in the lives of young people [24]. The introduction of the internet has made children and young people increasingly facilitated and get more opportunities to get learning resources from various sources. This may show the positive side of the proven era of disruption where the internet has contributed to supporting students' academic development, creativity, and social networking which ultimately can sustain their life quality. However, all these given opportunities brought on by the internet may not last without risk. The Ministry of Education and Culture argues that the disruption era has an impact on the character of Indonesia's young generation, including low tolerance among religious people, the use of illegal drugs, pornography that has penetrated children and adolescents. Meanwhile the Minister of Women's Empowerment and Child Protection or Pemberdayaan Perempuan dan Perlindungan Anak (PPPA) cited in nstionalkompas.com revealed that there are 25,000 Indonesian 
child pornography activities. In January 2019, a whatsapp group was used to coordinate ditching together by vocational students in Solo.

These cases are the abusive attitudes of using ICT among teenage students or popularly known as digital native. That is, an individual born after the adoption of digital technology [22]. The use of social media such as Facebook, Twitter, Instagram, and Path is a new vehicle for students to express and share ideas. In fact, not infrequently this media is called as a means in the search and recognition of the identity of teenagers, trade, exchange of ideas, and other significant impacts [3]. Even ironically, these activities actually trigger negative and dangerous things such as expressions of hate speech, online fraud, hoaxes, and the like [21]. This shows that technological progress has been a trigger for the decline of students' ethics. This study aims to find out how the digital ethics profile of students in the era of disruption in terms of internet use is at risk. This research contributes as the efforts in strengthening students' digital ethics.

\section{Review of Related Literature}

\subsection{Digital ethics as a digital civics component}

The term digital citizenship is a concept that describes the ideal characteristics of smart and good digital citizens. Cogan and Dericot [29] suggest the meaning of citizenship as a set of characteristics as citizens. Digital citizenship is defined as norms, and attitudes are responsible for the use of ICT. This refers to citizens who can regularly and effectively use the internet. Digital citizenship is perceived as a concept of citizens who are reliable in digital technology and adhere to ethics in the use of technology, this reflects the character of a good citizen. Digital citizenship is more than just a tool for teaching; however, it is a way of preparing students or users of technology to enter the life of a technology-dependent society. Digital citizenship as ethics refers to how to use the internet appropriately, safely, ethically, and responsibly in internet activities [5].

Digital ethics is a part of digital citizenship where everyone needs to obey, which this is further coined as netiquette. Netiquette, a hybrid word combining "network" and "etiquette," essentially referring to the social code of the Internet. As netiquette includes how we communicate, treat others, describe ourselves, and protect ourselves online related to ethical issues. Ethics, or moral philosophy, generally refers to how groups and individuals determine moral actions. Ethics refers to the way groups and individuals relate to, treat, and solve problems one another; digital ethics then includes how users and participants in the online environment interact each other and the technology and platforms used to engage [16]. Digital ethics or information ethics in a broader sense are related to the impact of using digital Information and Communication Technology (ICT) on social and environmental societies in general. In a narrower sense, information ethics (or digital media ethics) provides answers to ethical questions related to the internet and the media of internet communication and information such as cell phones and navigation services [4]. Digital ethics is the concept of norm attitude which is deemed appropriate and responsible in terms of using technol- 
ogy media. In line with this, a worrying issue that needs to be highly notified in this regard is whether students are capable of effectively developing their respective skills in this kind of environment. Some other things that might happen are students are capable of taking a great advantage through online transactions or even avoid themselves from the negative risks of online activities, such as dealing with strangers and committing cyber bullying [24] .This is highly important to provide security and comfort to other fellow digital citizens. The digital citizenship ethics are essentially important for all people who engage themselves in digital technology, which cover the use of language in expressing verbal opinions and ideas on social media, thus not offending others, providing relevant information instead of hoaxes, not involved in expressing typical hate speeches of SARA (Tribe, Religion, Race, and Intergroup), and other actions that potentially lead into negative or risky impacts.

\subsection{Students use of internet: the opportunities}

Children and adolescents as a digital native is inseparable from the internet use in their lives. This is as revealed in the UNICEF data that the number of children and adolescents who are internet users is greater, even reaching more than 30 million users. Furthermore, according to results of the study, these children and adolescents used the internet mostly for three main purposes; the first is to find out information related to school assignments and learning materials, second is for friendship, and third for entertainment. According to Livingstone \& Helsper [13] indicated there are at least six common opportunities for people to engage in online activities such as

- Information

- Communication

- Entertainment

- Participation

- Creativity

- Self-expression

Many studies show that the youth activities in using ICT have been used as the means of communication. In line with a research conducted in Malaysia [19] the most popular use that involves a number of school children including communication media such as Facebook (78\%), instant messaging (75\%), Email (41\%) Twitter (38\%), Chatroom (29\%) and Skype (23\%). Although some of them use it as a medium of help in doing school work $(86 \%)$, and entertainment activities by downloading songs or music $(25 \%)$. Opportunities for use in the categories of participation, creativity and expression, according to researchers, are found to be less popular with teenage students in Malaysia, for most of them are rarely or have never involved in such activities. A research conducted in Korea [9] found that a lower percentage of online participation was the children. Online participation concern the writings posted on blogs or personal sites, which are intended to (29.7\%) post articles on group sites $(28.8 \%)$; express opinions about social problems (28.4\%); link useful information to their blog (21.7\%); useful information recommended for other users (21.6\%); answer questions 
posted by other users $(29.0 \%)$; comment on other users' posts $(34.3 \%)$ and write comments regarding the products they bought (19.1\%). The survey results in Indonesia by the Association of Indonesian Internet Organizing Services (APJII) in 2017 revealed that the most dominant activities in the internet were for online-mediated communication (chat) of $(89.35 \%)$, social media $(87.13 \%)$, search engines $(74.84 \%)$, for the sake of entertainment such as downloading songs, pictures, videos $(67.35 \%)$, other activities such as selling / buying goods, and registration (8.91\%).

Based on the data above, it was concluded that the opportunity for students to use internet was most dominantly used as a medium of communication via chat and mail (online mediated-communication), as well as social media and blogs, these are the typical of online participation.

\subsection{Potential risks of internet use}

Online risk comes through internet mediated communication activities [13]. This is one of the effects of changes in communication patterns or interactions from online to online. Besides the benefits of increasing inter-community socialization, interpersonal communication and sustaining the learning opportunities for students, the use of social media enables other specific risks, including cyber bullying, sexting, sending obscene photos, public sharing locations, spreading mocking memes / jokes and dangerous games [3], [2]. Therefore, understanding the basic set of norms and values where people should adhere to on accessing information and interacting both verbally and visually through online is highly important to do. There are a number of potentially risk classifications for internet use.

Table 1. Opportunities and Risks of Using the Internet [14]

\begin{tabular}{|l|l|l|l|}
\hline & \multicolumn{1}{|c|}{$\begin{array}{c}\text { Content Receiving } \\
\text { mass-produced content }\end{array}$} & $\begin{array}{c}\text { Contact Participating in (adult- } \\
\text { initiated) online activity }\end{array}$ & $\begin{array}{c}\text { Conduct Perpetrator or } \\
\text { victim in peer-topper ex- } \\
\text { change }\end{array}$ \\
\hline Aggressive & Violent / gory content & Harassment, stalking & Bullying, hostile peer activity \\
\hline Sexual & Pornographic content & $\begin{array}{l}\text { 'Grooming', sexual abuse or } \\
\text { exploitation }\end{array}$ & Sexual harassment, 'sexting' \\
\hline Values & Racist / hateful content & Ideological persuasion & $\begin{array}{l}\text { Potentially harmful user gener- } \\
\text { ated content }\end{array}$ \\
\hline Commercial & Embedded marketing & Personal data misuse & $\begin{array}{l}\text { Gambling, copyright infringe- } \\
\text { ment }\end{array}$ \\
\hline
\end{tabular}

According to Dowel [30] categorized the attitudes of using internet at risk on adolescents, among others:

- To express personal information

- To insult others through online mediated-communication (harassment and cyber bullying)

- To communicate and build relationship with the strangers

- To access pornographic contents. 
Meanwhile, a research to European people on the internet security and risk identified several internet attitudes at risk for teenagers including:

- Pornography

- Bullying

- Sexting

- Offline contact online meetings [14].

Indonesia as one of the countries with the largest number of internet users in the world is inevitable from the risk of such use. UNICEF describes some of the risks associated with young internet users in Indonesia, including;

- Pornography and sexual exploitation

- Communicating and meeting foreigners through the internet

- Trafficking

- Software piracy

- Spreading extremist missions (by terrorist groups).

Based on a number of research sources discussed above, conclusion can be derived that attitudes towards the use of the internet at risk were specified for;

- Expressing individual's personal information

- Bullying / expressing hate speech

- Accepting the hoaxes

- Accessing the pornographic contents.

\subsection{Transformation in the era of disruption}

The implementation of industry 4.0 has inflicted fundamental changes in various part of people's lives. These occuring fundamental changes due to industry 4.0 were then referred to as the disruption era. With regard to disruption caused by industry 4.0, (Schwab, 2017) suggest that the impact of industry 4.0 was divided into five clusters, namely:

- Economic sector namely with economic growth, and the nature of work

- Business life with new innovations and the latest operating models

- National-Global Relationship through the highest level of international standard security

- Society related to attitudes of inequality and the emergence of new communities

- Individuals, a great influence to individual's morals and ethics, in addition to managing public and private information.

The disruption era has at least entered a new phase in the direction of the development of science and technological advances where the education sector is inevitable from these changes. The stakeholders in the education environment are expected to be able to respond positively to the changes in this revolutionary era 4.0 [6]. In the Era of Industrial Revolution 4.0, both the government and individuals need to develop new 
model of literacy. The new model of literacy typically includes data literacy, digital literacy and humanistic literacy. Data literacy includes the ability of the community to read, analyze and make thinking conclusions based on the data and information (big data) obtained. Digital literacy concerns the ability of individuals or communities to understand the workings of digital machines, the application of technology and work based on technology products aimed at producing maximum performance. Humanistic literacy is related to the ability of communication, collaboration, creative thinking, innovative and critical. Therefore, among the successful ways of facing transformation in the era of disruption, in addition to the need for related parties to develop students' digital literacy skills, they need to maintain a humanistic literacy balance.

\section{Methods}

This research applies quantitative research design using survey methods. The survey was given to three schools, each of which is a high school, public vocational high school and private vocational high school in the residency area of Surakarta. A total of 210 students from the age of 15 to 17 years participated as subjects using survey method. The questionnaire consisted of 16 statements referring to Likert's scale point of one to five. In this study, the considered sample criteria for students who involved were those who used new media such as using e-mail, social networking sites, games or online chat. In this case, the students and class-managed survey technique to collect data, they were recommended and decided by the teacher class of their schools. Students were freely asked questions for further clarification. The data of students' digital ethics were classified according to the three categories that adhere to standard deviation. The group boundary categories illustrated as follows:

Table 2. The Measuring Scale of Students' digital ethics

\begin{tabular}{|c|l|}
\hline \multicolumn{1}{|c|}{ Range } & \multicolumn{1}{|c|}{ Categories } \\
\hline$X>+\mathrm{S}=54,60$ & Good \\
\hline$X-{ }_{z}^{2} \mathrm{~S}=46,68 \leq \mathrm{X} \leq+{ }^{2}-\mathrm{S}=56,60$ & Enough \\
\hline $\mathrm{X}<-\mathrm{S}=46,68$ & Less \\
\hline Attitudes towards the internet use at risk & \multicolumn{1}{c|}{ Categories } \\
\hline Attitudes towards the internet use at risk with never intensity & Good \\
\hline Attitudes towards the internet use at risk with infrequently intensity & Enough \\
\hline Attitudes towards the internet use at risk with frequently intensity & Less \\
\hline
\end{tabular}

\section{$4 \quad$ Results and Discussion}

The research data obtained from the survey results on the students' digital ethics analyzed refers to their relevance to risky internet use. The data obtained in the field are then analyzed and presented in the description as illustrated in table 4. 
Table 3. Descriptive Statistics of Internet use at risk

\begin{tabular}{|l|c|c|c|}
\hline \multicolumn{1}{|c|}{ Variables } & Mean & $\mathbf{\%}$ & Standard Deviation \\
\hline Expressing about personal information & 17,40 & 34,8 & 2,61 \\
\hline Bullying/ hate speeches & 7,58 & 15,18 & 3,07 \\
\hline Accepting the hoaxes & 11,73 & 23,49 & 5,05 \\
\hline Accessing pornographicic contents & 13,20 & 26,43 & 4,06 \\
\hline
\end{tabular}

The data in table 3 shows that the use of the internet has the potential risk for students at the lowest average score in the variable bullying or hate speech, 7, and 58 . Accepting the hoaxes news is with average of 11.73 and pornographic content / access with average 13.20. Meanwhile, expressing personal information shows the highest average score of 17.40. Therefore, the data in this study indicate that the internet use at risk for students have been much on the attitudes of bullying at the highest frequency, while expressing personal information is at the lowest frequency or even infrequently done by average students. Cyber bullying refers to the conflict triggering attitudes, which is realized intentionally through digital technology [10]. The availability of digital technology access through Smartphone, tablets, and smart portable devices trigger cyber bullying attitudes. Many international studies have argued that schools as a context for cyber bullying situations frequently occur [33]. This creates a new challenge for both the school and parents who have at least tried to prevent and resolve the problem. Students' attitudes of bullying in the context of digital environment in this study are classifiable into several disrespecting attitudes including showing negative comments on other people's posts on social networks, bullying friends on whatsapp groups, although it was aimed to joke, write statuses with the hope that the targeted person's faults are publicly known in addition to virtually undermine other people. In addition to the previously explained data, as for internet at opportunities for students, students are indicated to frequently receive hoaxes news which shows a high percentage. Hoax or fake news defined in many ways, such as recurring problems used intentionally in the political arena. The spread of hoaxes can be either intentional or accidental. Irrelevant truths (post truth) deliberately spread information about falsehood. In addition, baseless information is defined as out of truth or irrelevant information [23]. The students in this study tend not to be able to classify which news items reflect the elements of hoaxes and not. In general, their interest in a news story is based on the title. Even without feeling the need to read the entire contents of a news article, immediately share the article link. This has at least become a common thread in the phenomenon of hoax news dissemination, where in the case of their students they do not know the truth underlying the published contents. The students' ability to access pornographic content needs more attention by the government, schools and those closest to them. Almost all respondents have accessed pornographic content either intentionally or not. Students see sexual content or pornography through the internet as a source of access to pornography including television, films and videos [14] Among the students' online activities discussed in this study include the way they are accessing pornographic nuanced content intentionally, sharing pornographic nuanced content on social networks and accessing telephones and sex chat. The results of this study reveal that students' digital ethics are categorized as follows: 
Table 4. The Students' Digital Ethics Categories

\begin{tabular}{|l|c|c|}
\hline \multicolumn{1}{|c|}{ Digital Ethics } & Frequency & \% \\
\hline Good & 67 & 31,90 \\
\hline Enough & 69 & 32,85 \\
\hline Less & 74 & 35,23 \\
\hline
\end{tabular}

The results of the research in the data above show that students' digital ethics with less categories have the highest percentage of $35.23 \%$. While $32.85 \%$ for the enough category and 31.90 for the good category. Digital ethics concerns the use of the internet or digital media properly and correctly, so that students' digital ethics become measurable based on their internet use at risk. Students who uphold digital ethics are well-suited to accessing the internet in digitally searching for things that do not conflict with the norms and rules of the digital community. There is no definite way in terms of codes of ethics about how users communicate or interact virtually. However, there are several conventions that need to be considered. Considering ethics as the "right" foundation in attitude and interacting with others in certain environments [16].

Digital ethics concerns the use of the internet or digital media properly and correctly, thus, students' digital ethics become measurable if examined from their internet use at risk. Students who are categorized as having digital ethics are well-suited to accessing the internet to digitally search for things that do not conflict with the norms and rules of the digital community. There is no definite way in terms of codes of ethics about how users communicate or interact virtually. However, there are several conventions that need to be considered. Considering ethics as the "right" foundation in attitude and interacting with others in certain environments [4]. Thus, digital ethics is inevitable for users, especially among students. There needs to be a strategy in strengthening digital ethics, especially for students as a digital native that is inseparable from the sophistication of ICT.

\subsection{Humanistic literacy as an effort to strengthen digital ethics}

In confronting the transformation of the disruption era, new literacy is needed which cover the data literacy, digital literacy and human literacy [11]. The application of humanistic literacy is a fundamental important thing in the current era of disruption. This is important to implement, given the importance of the role of humans to be a good role model for other fellow human beings in addition to understand the interaction properly among other users. Various virtual interactions include the interests of the educational realm more specifically in the school environment. For this reason, the task of education today through the learning process that not only emphasizes the strengthening of old literacy competencies, but simultaneously reinforces and supports new literacy that is relevant to the real life of today's students.

The digital age is currently leading us to a new era of character education, where both students and instructors are wisely required to accept the opportunities and overcome challenges in living a digital lifestyle [18].With regard to humanistic literacy, UNESCO suggested that literacy skills have become the right of every person and is considered the basis for lifelong learning. Literacy skills enable both individuals, 
families, and communities to empower and improve their life qualities. Given the "multiple effects" or can provide effects in a very broad domain, literacy capabilities contribute significantly to eradicating poverty, reducing child mortality, population growth, and ensuring sustainable development, and supporting the realization of peace. Whereas illiteracy, however, is a human obstacle in realizing a better quality of life. Thus, it is important to note that the idea that the digital era requires us to bring new nuances to character education, where its existence triggers the opening of opportunities and challenges in the digital lifestyle of modern humans. The role of the school environment as one of the realization of humanistic literacy today remains in seeking its form through the learning process. Learning in schools through the 2013 curriculum explicitly establishes learning methods that are part of the constructivists themselves. Thus, these results further emphasize the importance of humanistic literacy where in this era of disruption has become a trend in dealing with the industrial revolution 4.0 [25].

Pancasila and Civics Education share strategic roles in fostering the character of students in Indonesia. This is in line with the opinion of Sapriya [23] that one of the roles of the Civics Education is as a vehicle for national character education, in addition to values and moral education. One of these efforts was realized through the Value Clarification Technique learning model. The value clarification technique approach, more popularly known as VCT, is a value education approach where participants are trained in finding, choosing, analyzing, deciding, and taking attitudes individually towards the values of life they are fighting for [1]. VCT facilitates direction for students to strive to assess their own feelings and actions, while increasing their individual awareness about the values in themselves. The teacher(s) consider that the current traditional moral education method is considered not functioning effectively. A research conducted in Romania revealed that teachers were able to master the Value Clarification Technique and succeeded in applying it in the classroom. They value the training programs they take and are willing to obtain new information and skills about moral education. They are a real source of implementing programs to make moral education more effective. Both teachers and students agreed that the use of VCT significantly contributed to the creation of a more motivating and enjoyable learning environment [12]. This allows students to be trained in determining their own attitudes so that all violations of digital ethics can be avoided both during the lesson and in the context of personal accessing online.

\section{Conclusion}

Technological advances in the era of disruption become unavoidable for most modern societies, especially in Indonesia of today. It is a significant orientation to prepare citizens who are sensitive to the digital world and adaptable to positively engage in it. The results of this research indicate that students' level of digital ethics as part of the digital citizenship only reaches $35.23 \%$ categorized as less. The variables of both bullying and news hoax show the highest frequency found in students' internet use, which concludes that students are urgently vulnerable to such activities, 
that mostly they were less capable of avoiding themselves over the use of technology in their everyday lives. To cope with that problem, we need a learning innovation, one of which is through Civics Education Learning. The education unit needs to develop new literacy that students should have, including data literacy, digital literacy and humanistic literacy. Civics Education holds a significant role as a vehicle for national character, values and moral education. Civics Education enables the humanistic literacy be applied through the Value Clarification Technique learning model. This research emphasizes the importance of humanistic literacy to strengthen students' digital ethics in dealing with the technological advancement in the era of disruption.

\section{$6 \quad$ References}

[1] Adisusilo, S. Pembelajaran Nilai Karakter. Jakarta: Raja Grafindo Persada, 2013

[2] Ahern, N. R., Sauer, P. \& Thacker, P. (2015). Risky behaviors and social networking sites: how is YouTube influencing our youth?, Journal of psychosocial nursing and mental health services, 53, (10), 2015, pp.25-29. https://doi.org/10.3928/02793695-20150908-01

[3] Branley, D. B. \& Covey, J. (2018). Risky behavior via social media: The role of reasoned and social reactive pathways. Computers in Human Behavior, 78, (2018), pp. 183-191. https://doi.org/10.1016/j.chb.2017.09.036

[4] Capurro, R. (2017). Digitization as an ethical challenge. Ai \& Society, vol.32, (2), 2017, pp. 277-283. https://doi.org/10.1007/s00146-016-0686-z

[5] Choi, M. (2016). A Concept Analysis of Digital Citizenship for Democratic Citizenship Education in the Internet Age, Theory \& Research in Social Education, vol. 44, (4), 2016, pp. 565 607, https://doi.org/10.1080/00933104.2016.1210549

[6] Huda, M. M. K. S. Teh, N.N., Muhamad, H., \&Nasir, M. B. (2018). Transmitting leadership based civic responsibility: insights from service learning. International Journal of Ethics and Systems, 34, (1), (2018), pp. 20-31. https://doi.org/10.1108/IJOES-05-2017-0079

[7] Janssen, J., Stoyanov, S. Ferrari, A., Punie, Y., Pannekeet, K., \& Sloep, P. (2013). Experts' views on digital competence: Commonalities and differences. Computers \& Education, 68, 2013, pp. 473-481. https://doi.org/10.1016/j.compedu.2013.06.008

[8] Ketelaar, P. E., \& van Balen, M. (2018). The Smartphone as your follower: The role of Smartphone literacy in the relation between privacy concerns, attitude and behavior towards phone-embedded tracking. Computers in Human Behavior, 78, 2018, pp.174-182. https://doi.org/10.1016/j.chb.2017.09.034

[9] Lee, S.-J. \& Chae, Y.-G., (2012), Balancing participation and risks in children's Internet use: the role of internet literacy and parental mediation. Cyber psychology, behavior and social networking, 15, (5), 2012, pp.257-262. https://doi.org/10.1089/cyber.2011.0552

[10] Li, Q., Wang, Z., \& Pustaka, A. (2015). Mobile technology and cyber bullying. In Encyclopedia of mobile phone behavior, IGI Global. 2015, pp. 705-718 https://doi.org/10.4018/978-1$\underline{\text { 4666-8239-9.ch058 }}$

[11] Li, S., \& Liu, B., Aoun, J.E. (2017). Robot-proof: higher education in the age of artificial intelligence: MIT Press, Kindle edition https://doi.org/10.1007/s10734-018-0289-3

[12] Lisievici, P., \& Andronie, M. (2016). Teachers Assessing the Effectiveness of Values Clarification Techniques in Moral Education. Procedia - Social and Behavioral Sciences, 217, 2016, pp.400-406. https://doi.org/10.1016/j.sbspro.2016.02.111 
[13] Livingstone, S. (2008). Taking risky opportunities in youthful content creation: teenagers' use of social networking sites for intimacy, privacy and self-expression. New Media \& Society, 10, (3), 2008, pp. 393-411. https://doi.org/10.1177/1461444808089415

[14] Livingstone, S., Haddon, L., Görzig, A.A., \& Ólafsson, K. (2011). "Risks and safety on the internet: the perspective of European children: full findings and policy implications from the EU Kids Online survey of 9-16-year olds and their parents in 25 countries”, 2011.

[15] Livingstone, S., \& Helsper, E. (2009). Balancing opportunities and risks in teenagers' use of the internet: the role of online skills and internet self-efficacy. New Media \& Society, 12, (2), 2009, pp.309-329. https://doi.org/10.1177/1461444809342697

[16] H. McKee, (2002), "Your Views Showed True Ignorance!": (Mis)Communication in an online interracial discussion forum. Computers and Composition, 19, (4), 2002, pp.411-434. https://doi.org/10.1016/S8755-4615(02)00143-3

[17] Muhuri, P. K., Shukla, A. K. \& Abraham, A. (2018), Industry 4.0: A bibliometric analysis and detailed overview. Engineering Applications of Artificial Intelligence, 78, 2019, pp.218-235. https://doi.org/10.1016/j.engappai.2018.11.007

[18] Ohler, J. (2011). Digital citizenship means character education for the digital age. Kappa Delta Pi Record, 47, (1), 2011, pp.25-27 https://doi.org/10.1080/00228958.2011.10516720

[19] Omar, S.Z., Daud, A., Hassan, M.S., Bolong, J. \& Teimmouri, M. (2014), Children Internet Usage: Opportunities for Self Development. Procedia - Social and Behavioral Sciences, vol. 155, 2014, pp. 75-80. https://doi.org/10.1016/j.sbspro.2014.10.259

[20] Porat, E., Blau, I. \& Barak, A. (2018). Measuring digital literacies: Junior high-school students' perceived competencies versus actual performance. Computers \& Education, 126, 2018, pp.2336. https://doi.org/10.1016/j.compedu.2018.06.030

[21] Pramanda, A., Muchtarom, M. \& Hartanto, V.P. R. (2018). Penguatan Etika Digital Pada Siswa Untuk Menanggulangi Penyebaran Berita Bohong (Hoax) Di Media Sosial Melalui Pendidikan Kewarganegaraan, 21, 2018.https://doi.org/10.20961/paedagogia.v21i2.23922

[22] M. Prensky, (2004), "The emerging online life of the digital native", August 7, 2004.

[23] Purnomo, M. H. Sumpeno, S. Setiawan, E. I., \& Purwitasari, D. (2017). Keynote Speaker II: Biomedical Engineering Research in the Social Network Analysis Era: Stance Classification for Analysis of Hoax Medical News in Social Media. Procedia Computer Science, 2017, pp. 116, 3-9. https://doi.org/10.1016/j.procs.2017.10.049

[24] Rodríguez-, de-D. I., van Oosten, J. M. F., \& Igartua J.-J. (2018), A study of the relationship between parental mediation and adolescents' digital skills, online risks and online opportunities. Computers in Human Behavior, 82, 2018, pp.186-198. https://doi.org/10.1016/ j.chb.2018.01.012

[25] Sanjayanti, N. P. A. H. Qondias, D., Wardana, M. A. K, \& Darmayanti, N. W. S. (2018), Diagnosa Literasi Humanistik dalam Model Pembelajaran Konstruktivis pada Mahasiswa Politeknik Ganesha Guru”. Seminar Nasional Riset Inovatif SENARI 2018, 6, 2018.

[26] Schwab, K. (2016). The fourth industrial revolution. New York: Crown Business. In. Siddiq, F., Hatlevik, O. E., Olsen, R. V., Throndsen, I., \& Scherer, R. Taking a future perspective by learning from the past - A systematic review of assessment instruments that aim to measure primary and secondary school students' ICT literacy. Educational Research Review, 19, 2016, pp. 58-84. https://doi.org/10.1016/j.edurev.2016.05.002

[27] Smith, P. K. (2012). Cyber bullying: Challenges and opportunities for a research program-A response to Olweus. European Journal of Developmental Psychology, 9, (5), 2012, pp.553-558. https://doi.org/10.1080/17405629.2012.689821

[28] Williams, E. J., Beardmore, A. \& Jonson, A. N. (2017), Individual differences in susceptibility to online influence: A theoretical review. Computers in Human Behavior, 72, 2017, pp.412421. https://doi.org/10.1016/j.chb.2017.03.002 
[29] Sapriya, Istanti, T., \& Zulkifli, E. (2007), Pengembangan Pendidikan IPS di SD. Bandung: UPI Press

[30] Adityar. The Effect of Digital Literacy on the Risky Internet Behavior among Senior Secondary School in Makassar. [Unpublished Thesis]. Program Pascasarjana Fakultas Ilmu Sosial Dan Ilmu Politik Universitas Hasanuddin Makassar, 2017

\section{$7 \quad$ Authors}

Dewi Ika Sari is a student of master program in Civics Education Department, Faculty of Teacher Training and Education. Sebelas Maret University. Email: dewiika@student.uns.ac.id

Dr. Triana Rejekiningsih, S.H., K.N., M.Pd. is a lecturer in Civics education department of Sebelas Maret University. She has completed her undergraduate education in 1998 from School of Law, Sebelas Maret University. Then graduated from her master's education at Gadjah Mada University in 2002, and completed her doctoral education at the Indonesian Education University in 2014. Dr. Triana Rejekiningsih has conducted a number of studies. She has actively participated in various researches at internal campus level and the Ministry of Research and Technology. Additionally, she also has actively published his writings in several internationally reputed journals. Email: triana_rizq@staff.uns.ac.id

Dr. Moh. Muchtarom, S.Ag, M.Si. is a lecturer in Pancasila and Civics Education Department (PPKn), Faculty of Teacher Training and Education, Sebelas Maret University. He has been actively involved in various education service activities and researches in the field of political philosophy, and Civics Education. Email: muhtarom1974@gmail.com

Article submitted 2019-10-04. Resubmitted 2019-11-17. Final acceptance 2019-11-24. Final version published as submitted by the authors. 